\title{
Downregulation of $R B B P 6$ variant 1 during arsenic trioxide-mediated cell cycle arrest and curcumin-induced apoptosis in MCF-7 breast cancer cells
}

\author{
Lilian Makgoo ${ }^{1}$, Kagiso Laka ${ }^{1}$ \& Zukile Mbita*,1 \\ ${ }^{1}$ Department of Biochemistry, Microbiology, \& Biotechnology, University of Limpopo, Private Bag x1106, Sovenga, 0727, \\ Polokwane, South Africa \\ *Author for correspondence: Tel.: +27 15268 3019; Zukile.Mbita@ul.ac.za
}

\begin{abstract}
Aim: To determine the expression patterns of the RBBP6 spliced variants during arsenic trioxide-mediated cell cycle arrest and curcumin-induced apoptosis in MCF-7 cells. Materials \& methods: $\mathrm{As}_{2} \mathrm{O}_{3}$ and curcumin were used to study cytotoxicity, cell cycle arrest, apoptosis and the expression of RBBP6 variants. The MUSE Cell Analyser was used to analyze cell cycle arrest, apoptosis and multicaspase activity while apoptosis was further confirmed using microscopy. Semi-quantitative RT-PCR was employed to quantitate the expression of the RBBP6 variants. Results: This study showed that the MCF-7 cells expressed RBBP6 variant 1 but lacked both variant 2 and variant 3 . Both $\mathrm{As}_{2} \mathrm{O}_{3}$ and curcumin significantly downregulated $R B B P 6$ variant 1 ( $\mathrm{p}<$ 0.001). Conclusion: RBBP6 variants are promising therapeutic targets.
\end{abstract}

Lay abstract: Understanding how breast cancer develops remains to be fully understood. It is known that genes play a pivotal role in the carcinogenesis process. The RBBP6 gene, which has different variants, has been reported to be involved in cancer development but it remains unclear which RBBP6 product is involved in cancer development. This study has demonstrated that there are RBBP6 variants that are pro-carcinogenic and those that are anti-carcinogenic. This study further showed that arsenic trioxide and curcumin lowered the expression of the RBBP6 splice variant 1 in MCF-7 breast cancer cells. Therefore, targeting $R B B P 6$ variants for future drug development is a promising strategy.

First draft submitted: 3 April 2019; Accepted for publication: 7 June 2019; Published online: 30 July 2019

Keywords: apoptosis $\bullet$ arsenic trioxide $\bullet$ breast cancer $\bullet \mathrm{G} 2 / \mathrm{M}$ arrest $\bullet$ RBBP6 $\bullet$ splicing

Cancer is an uncontrollable growth of cells due to loss of cell growth regulation, which normally results in high proliferation rates, resistance to apoptosis and activation of survival pathways. Breast cancer is no exception to this trend and is the most aggressive and leading cause of death among woman, worldwide [1]. Despite the progress made in the improvement of breast cancer treatment strategies, it is still difficult to destroy breast cancer cells without affecting the normal cells and minimize the long- and short-term side effects associated with the current breast cancer treatment [2].

Gene therapy has attracted a lot of interest for breast cancer treatment. The search for regulatory biomolecules involved in the carcinogenesis process has also intensified. $R B B P G$ is one of the genes that has shown great potential as therapeutic targets [3-5]. RBBP6 is a protein encoded by the RBBP6 gene located in chromosome 16p12.2. In humans, the $R B B P 6$ gene is transcribed into three proven spliced variants due to alternative splicing [4]. However, Ntwasa $e t a l$. [6]. reported the existence of a fourth variant due to alternative splicing. These alternatively spliced variants include a $6.1-\mathrm{kb}$ mRNA transcript and a $1.1-\mathrm{kb}$ mRNA transcript (variant 3 ). The $6.1 \mathrm{~kb}$ variant is further alternatively spliced into two mRNA variants, one containing exon 16 (variant 1) while the other lacks exon 16 (variant 2), consequently resulting in three mRNA transcripts [4]. Variant 3 is translated into RBBP6 isoform 3. Isoform 1 is made of 1792 amino acids, followed by isoform 2 with 1758, and last isoform 3 with 118 amino 
acids [4]. Recently, it was reported that there are four isoforms but it is not clear how the fourth isoform is derived. The hypothetical isoform 4 has been reported to have 952 amino acids [7] and its function remains a mystery.

Little is known about the expression and regulation of human $R B B P 6$ splice variants during cell cycle progression and breast cancer development. Previously, one study had reported the involvement of the RBBP6 rat homolog [8], proliferation potential protein-related (P2P-R), in mitotic apoptosis. It is only Mbita et al. that implicated the human RBBP6 in cell cycle regulation [4]. Recently, another study reviewed the role of $R B B P 6$ in carcinogenesis, implicating $R B B P G$ as a key role player in both carcinogenesis and cell cycle regulation [7].

The expression of the $R B B P G$ transcripts is not fully understood, especially during cell cycle arrest and apoptosis in breast cancer. This study explores the possible involvement of $R B B P 6$ transcripts in breast cancer development and their roles in the regulation of cell cycle and apoptosis. In this paper, the analysis of RBBPG transcripts during cell cycle arrest and apoptosis was carried out to assess the possible involvement of $R B B P G$ variants in the carcinogenesis process, using MCF-7 breast cancer cells. Deregulation of both cell cycle and apoptosis are some of the manifestations of the carcinogenesis process. Arsenic trioxide and curcumin have been shown to induce cell cycle arrest and apoptosis while cobalt chloride has been demonstrated to induce cell cycle arrest [9-11]. The latter was an appropriate cell cycle arrest positive control [11]. The roles of arsenic trioxide and curcumin in cell cycle arrest and apoptosis induction are well understood. Both cytotoxic agents were therefore suitable for studying the expression of RBBPG transcripts during cell cycle arrest and apoptosis of MCF-7 breast cancer cells.

\section{Materials \& methods}

Cell lines, cell culture maintenance $\&$ reagents

The breast cells, MCF-7 (ATCC-HTB-22, biosafety level II), were kindly donated by Prof Mervin Meyer from the University of the Western Cape who had purchased the cells from the American Type Culture Collection (ATCC, VA, USA). The MCF-7 cells were cultured in complete medium (Dulbecco's Modified Eagle's Medium [DMEM] supplemented with $10 \%$ fetal bovine serum [FBS] and $1 \%$ penicillin-streptomycin-neomycin) in a humidified atmosphere of $5 \% \mathrm{CO}_{2}$ at $37^{\circ} \mathrm{C}$. Curcumin, arsenic trioxide, cobalt chloride and MTT [3-(4, 5-dimethythiazol2-yl)-2, 5-diphenyltetrazolium bromide] were bought from Sigma-Aldrich (South Africa).

\section{MTT assay}

The effect of arsenic trioxide on the growth and viability of MCF-7 cells was assessed using the MTT assay. Briefly, breast cancer cells (MCF-7) were seeded in a 96-well microtiter plate at $4 \times 10^{3}$ cells/well and exposed to various concentrations of $\mathrm{As}_{2} \mathrm{O}_{3}(0-64 \mu \mathrm{M} / \mathrm{ml})$ for $24 \mathrm{~h}$ after allowing them to attach, overnight. After $24 \mathrm{~h}$, the treatment was removed followed by addition of $10 \mu \mathrm{l}$ of MTT $(5 \mathrm{mg} / \mathrm{ml})$ into each well and an additional 4-h incubation at $37^{\circ} \mathrm{C}$. An MTT solution was aspirated off and, $100 \mu \mathrm{l}$ of DMSO was added into each well to achieve solubilization of the formazan crystals formed in viable cells before absorbance at $570 \mathrm{nM}$ could be measured, using a GloMax-Multi+ (Promega, WI, USA). Cell survival rate was calculated using the following formula:

$$
\text { Survival rate }(\%)=\frac{\text { Average OD }(\text { experimental group })}{\text { Average OD }(\text { Untreated group })} \times 100 \%
$$

The MTT assay was also performed for the positive control (cobalt chloride).

\section{Morphological assessment of apoptosis using DAPI staining \& light microscopy}

DAPI staining was used for the morphological evaluation of MCF-7 cells after the treatment with arsenic trioxide and curcumin, as well the positive control (cobalt chloride). Briefly, MCF-7 cells were plated at a density of $4 \times 10^{3}$ cells per well in a six-well plate in a complete medium for $24 \mathrm{~h}$ and starved for further $12 \mathrm{~h}$ for synchronization. The cells were treated with arsenic trioxide, curcumin and cobalt chloride for $24 \mathrm{~h}$. After incubation, the cells were washed with $1 \times$ PBS and stained with $5 \mu \mathrm{g} / \mathrm{ml}$ DAPI for morphologic assessment of apoptosis using the Nikon Eclipse TS100F Ti-E inverted microscope (Nikon Instruments, Shinagawa, Japan).

\section{Cell cycle arrest analysis}

The MCF-7 cells were plated at a density of $4 \times 10^{3}$ cells per T-25 culture flask in a complete medium for 24 $\mathrm{h}$, and further starved for $12 \mathrm{~h}$ to synchronize the cells. After 24-h treatment with $\mathrm{IC}_{50} \mathrm{~s}$ for arsenic trioxide and the positive control (cobalt chloride), the relative number of cells in distinct cell cycle phases were assessed using 
the Muse ${ }^{\mathrm{TM}}$ Cell Cycle Kit following the manufacturer's instructions (Merck Millipore, Darmstadt, Germany) and analyzed using the Muse ${ }^{\circledR}$ Cell Cycle Analyzer (Merck Millipore).

\section{Multi-caspase assay}

The MCF-7 cells were cultured in 6-well plates, overnight; starved for $12 \mathrm{~h}$ and treated for $24 \mathrm{~h}$ with curcumin, which also served as a positive control and arsenic trioxide concentrations (11 and $32 \mu \mathrm{M})$. After treatment with the arsenic trioxide and the positive control (curcumin), the percentages of cells with activated caspases were quantified using the Muse ${ }^{\top M}$ Multi-Caspase kit following the manufacturer's instructions (Merck Millipore) and analyzed using the Muse Cell Analyzer.

\section{Apoptosis assay}

The MCF-7 cells were cultured in 6-well plates and allowed to settle overnight; starved for $12 \mathrm{~h}$ and then treated for $24 \mathrm{~h}$ with curcumin, which also served as a positive control and arsenic trioxide concentrations (11 and $32 \mu \mathrm{M})$. After treatment with arsenic trioxide and curcumin, the percentages of apoptotic cells were quantified using the Annexin V/FITC kit following the manufacturer's instructions (Merck Millipore) and analyzed using the Muse Cell Analyzer.

\section{Semi-quantitative reverse transcription polymerase chain reaction}

The MCF-7 cells were plated at a density of $4 \times 10^{3}$ cells per T-25 culture flask in complete medium for $24 \mathrm{~h}$ and starved for further $12 \mathrm{~h}$. The cells were then treated with arsenic trioxide, cobalt chloride and curcumin and incubated for $24 \mathrm{~h}$. The untreated control and the treated samples were washed with $1 \times$ PBS, twice. Total RNA from all the cell groups was extracted using the TRIzol reagent (Thermo Fisher Scientific, MA, USA) and reverse transcription (RT) was performed using the AMV reverse transcription system manufacturer's instructions (Promega, WI, USA). cDNA was amplified using both the $G A P D H$ primers (forward primer: AGCTGAACGGGAAGCTCACT; reverse primer: TGCTGTAGCCAAATTCGTTG) and RBBPG primer sets specific to different variants:

(RBBP6 variant 3 - forward primer: GGATAATATGTGGCATCACTTG; reverse primer: TCCCTGTATGACACTGTGTTG and RBBPG variant 1 and 2 - forward primer: GTATAGTGTCCCTCCTCCAGG; reverse primer: GTAATTGCGGCTCTTGCCTCT). The PCR reactions were prepared using a $2 \times$ PCR Master Mix (Takara Bio Inc., Kusatsu Japan) according to the manufacturer's instructions. The reactions were subjected to 30 cycles comprising the three PCR steps (denaturation, annealing and extension) in the T100 Thermal Cycler (Bio-Rad, CA, USA). The products were electrophoresed on 1\% agarose gels using a 100 bp DNA molecular weight marker (BioLabs, MA, USA) to confirm the sizes of the PCR products.

\section{Immunocytochemistry assay}

To evaluate the effect of arsenic trioxide on the expression and localization of Bax protein, immunofluorescence staining was performed. Breast cancer cells (MCF-7) were seeded on cover slips in 6-well plates at $1 \times 10^{5}$ cells/well and exposed to various concentrations of $\mathrm{As}_{2} \mathrm{O}_{3}(11$ and $32 \mu \mathrm{M})$, cobalt chlorite $(100 \mu \mathrm{M})$ and curcumin $(100 \mu \mathrm{M})$ for $24 \mathrm{~h}$. After the 24-h incubation, the cells were washed twice with $1 \times$ PBS and fixed in $4 \%$ paraformaldehyde for $15 \mathrm{~min}$ at room temperature. After fixing, the cells were permeabilized with $0.25 \%$ Triton $^{\mathrm{TM}}$ $\mathrm{X}-100$ for $10 \mathrm{~min}$ at room temperature. Antibody-nonspecific binding was blocked using $0.5 \%$ BSA for $1 \mathrm{~h}$ at room temperature. Following blocking, the cells were incubated with anti-Bax primary antibody (Lot\# E0707; Santa Cruz Biotechnology, TX, USA). A 1:50 dilution of the primary antibody was prepared in 1X PBS-BSA $(0.5 \%)$ and incubated for one $\mathrm{hr}$ at room temperature. The cells were washed with sterile $1 \times \mathrm{PBS}$, then labeled with Flour ${ }^{\circledR} 488$ goat anti-mouse IgG secondary antibody (Lot\# 1810918; Thermo Fisher Scientific, MA, USA). The cells were counter-stained with DAPI $(5 \mu \mathrm{g} / \mathrm{ml})$ for $10 \mathrm{~min}$ and examined under the Nikon Eclipse TS100F Ti-E inverted microscope (Nikon Instruments, Shinagawa Japan).

\section{Statistical analysis}

The results of the different experiments (cell viability assay, cell cycle phases analysis and apoptosis analysis) performed in triplicates were expressed as the mean \pm standard deviation (SD) using Instat Version 3 statistical software. Data were analyzed to get statistical significant differences by comparing two datasets (the untreated samples were compared with the treated samples) and the differences were considered significant when ${ }^{*} \mathrm{p}$ was $\leq$ $0.05,{ }^{* *} \mathrm{p} \leq 0.01$ and ${ }^{* * *} \mathrm{p} \leq 0.0001$. 
(A)

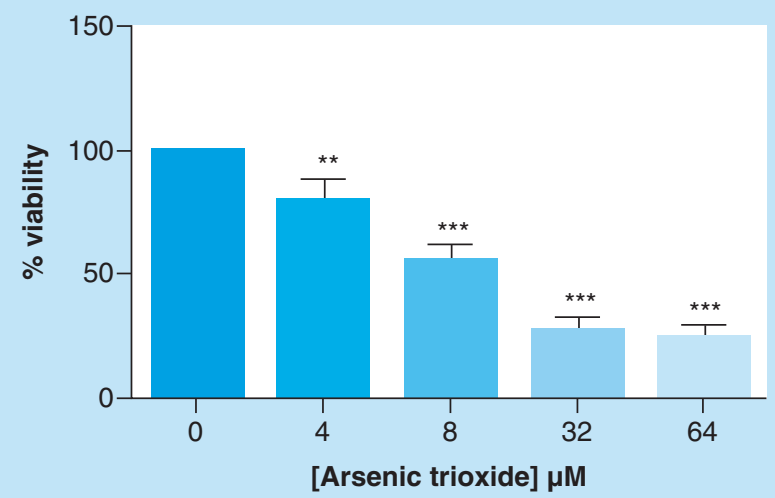

(B)

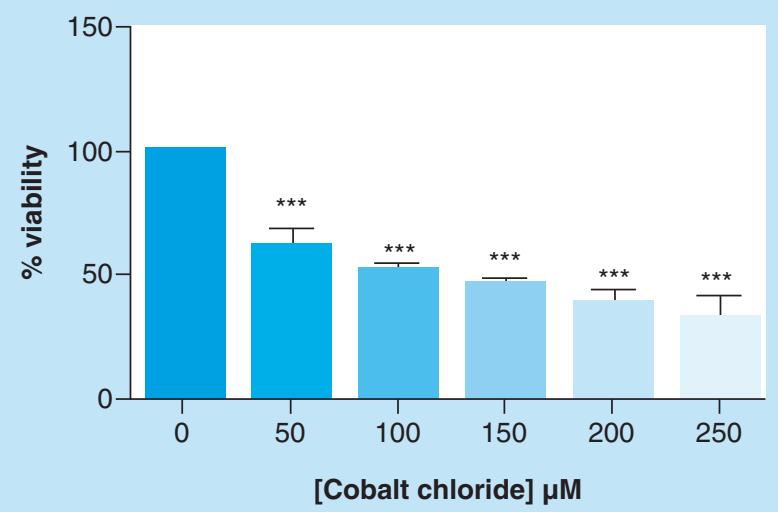

(C)

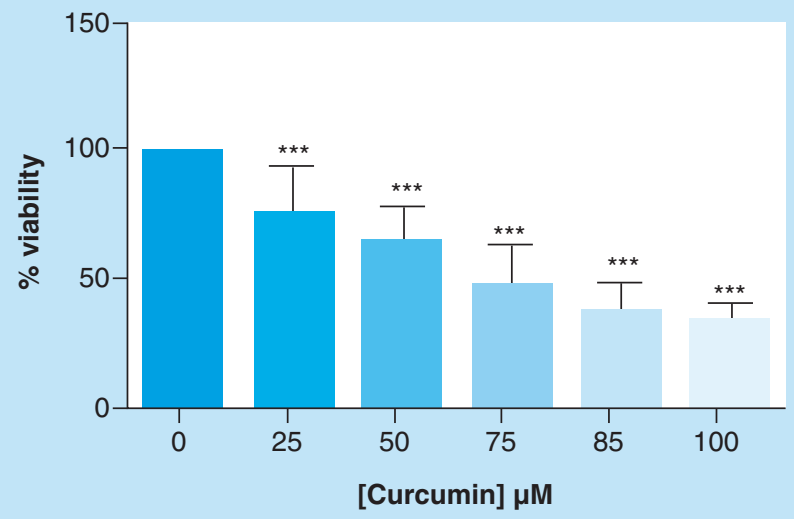

Figure 1. Cell viability analysis of the effect of arsenic trioxide, cobalt chloride and curcumin on MCF-7 cells. (A) The effect of arsenic trioxide $\left[\mathrm{As}_{2} \mathrm{O}_{3}\right]$, (B) cobalt chloride $\left[\mathrm{CoCl}_{2}\right]$ and $(\mathrm{C})$ curcumin on the cell growth and viability of the human breast cancer MCF-7 cells. All the three compounds inhibited viability of MCF-7 cells in vitro when compared with the untreated control cells. Results were obtained from three independent experiments and were presented as \pm standard error of the mean and the differences were considered significant when ${ }^{* *} p \leq 0.01$ and ${ }^{* * *} p \leq 0.001$.

\section{Results}

In vitro inhibition of MCF-7 cell growth by arsenic trioxide

The effect of arsenic trioxide on the growth and viability of MCF-7 cells was assessed using MTT assay. As shown in Figure 1A, the arsenic trioxide significantly inhibited the growth and viability of MCF-7 cells in a dose-dependent 

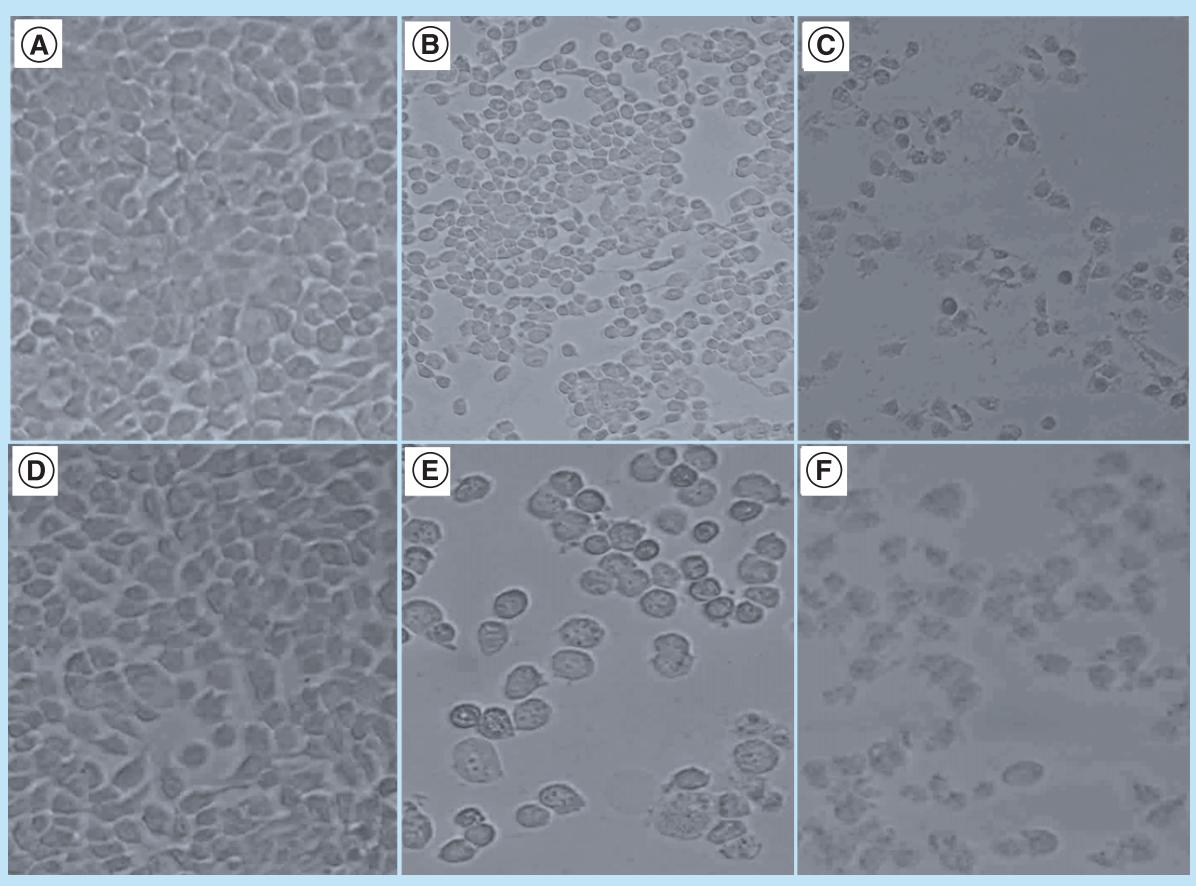

Figure 2. Light microscopy analysis of the effect of arsenic trioxide, cobalt chloride and curcumin on the morphology of MCF-7 cells. Morphological characteristics of MCF-7 cells after the treatment for $24 \mathrm{~h}$ with (2B) $11 \mu \mathrm{M}$ and (2E) $32 \mu \mathrm{M}$ arsenic trioxide, (2C) $100 \mu \mathrm{M}$ cobalt chloride and (2F) $100 \mu \mathrm{M}$ curcumin as compared with (2A \& 2D) untreated cells.

manner, with the extrapolated $\mathrm{IC}_{50}$ of $11 \mu \mathrm{M}$ and apoptosis-inducing concentration of $32 \mu \mathrm{M}$ after 24 -h treatment. After 24-h incubation, cobalt chloride (positive control for cell cycle analysis) also inhibited cell growth of MCF-7 cells at an $\mathrm{IC}_{50}$ of $100 \mu \mathrm{M}$ (Figure 1B). After 24-h incubation, curcumin, which was also used as a positive control for apoptosis assay, reduced the growth of MCF-7 cells between 85 and $100 \mu \mathrm{M}$ concentration (Figure 1C). These results demonstrated that arsenic trioxide was potent in inhibiting the proliferation and inducing death of MCF-7 cells in vitro.

\section{Morphological changes of MCF-7 cells due to cell cycle arrest \& apoptosis}

The treatment of the MCF-7 cells with arsenic trioxide, cobalt chloride and curcumin reduced the MCF-7 cell growth and adherence compared with the untreated control cells. Using DAPI staining and the inverted phasecontrast microscopy, 11 and $32 \mu \mathrm{M}$ arsenic trioxide, $100 \mu \mathrm{M}$ curcumin and $100 \mu \mathrm{M}$ cobalt chloride affected the morphology of the MCF-7 cells exposed for $24 \mathrm{~h}$. Many cells, consequently, shrunk, which is typical of cells undergoing apoptosis and evidently, losing their epithelial morphology (Figure 2A-F).

DAPI staining revealed that treatment with arsenic trioxide $(11$ and $32 \mu \mathrm{M})$ and the positive controls (cobalt chloride and curcumin) induced typical apoptotic morphology. These included nuclear condensation, lost microvillus and apoptotic body formation (Figure 3A-F). The changes confirmed that arsenic trioxide induced typical cytomorphological features of apoptosis in MCF-7 cells. Loss of microvilli, nuclear condensation and fragmentation were observed after the 24-h treatment of MCF-7 cells with arsenic trioxide (11 and $32 \mu \mathrm{M})$, curcumin $(100 \mu \mathrm{M})$ and cobalt chloride $(100 \mu \mathrm{M})$.

\section{Arsenic trioxide induces G2/M cell cycle arrest in MCF-7 cells}

The effect of $\mathrm{As}_{2} \mathrm{O}_{3}$ and the cell cycle arrest positive control, cobalt chloride, on MCF-7 cells was observed. Both inducers increased the G2M cell population where the treatment with $11 \mu \mathrm{M}$ of arsenic trioxide showed an increase in the population of G2/M phase cells after $24 \mathrm{~h}$ and decreased the G1 population (Figures $4 \& 5$ ) relative to the untreated control. This trend was also observed for the treatment with the positive control, $100 \mu \mathrm{M}$ cobalt chloride. 


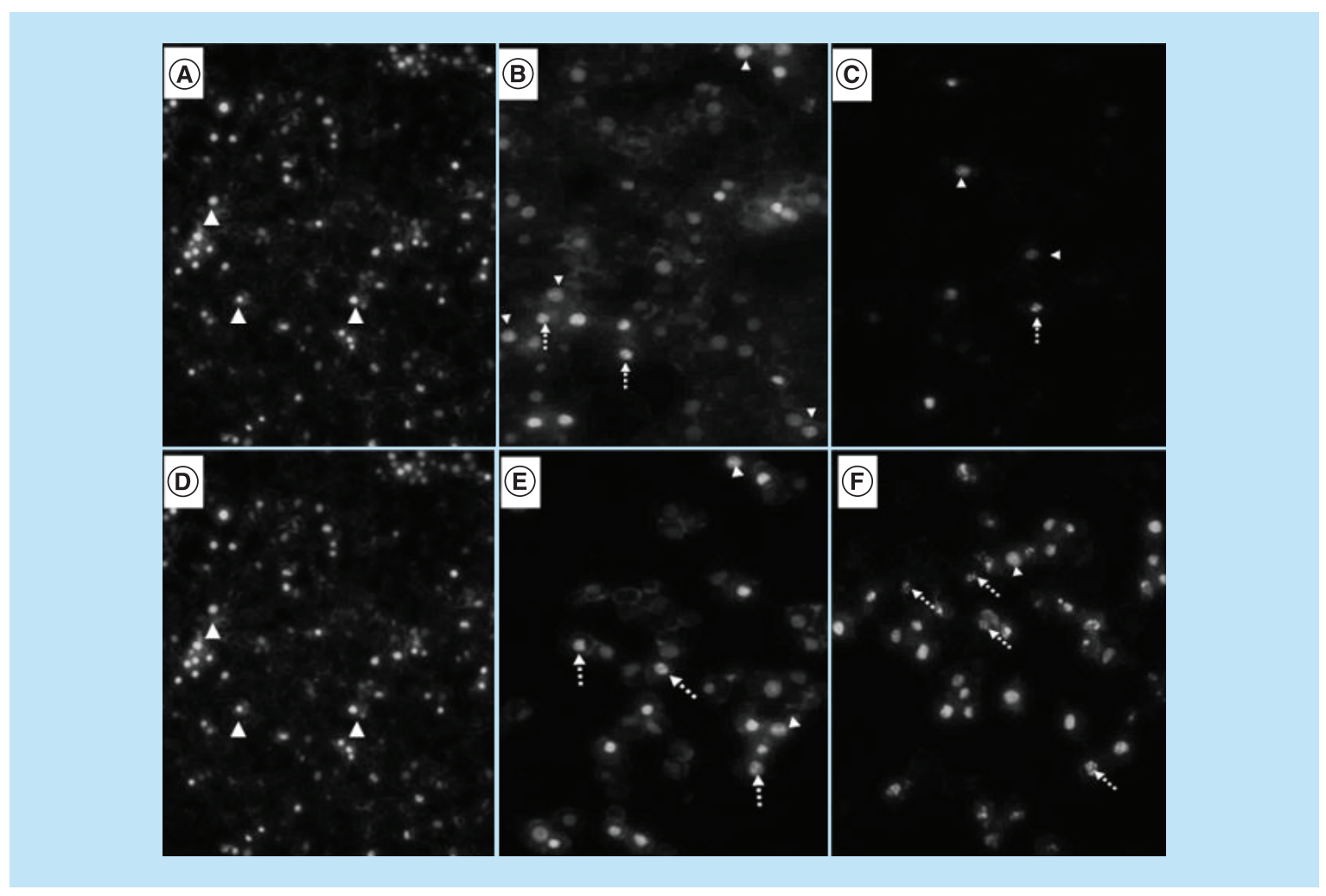

Figure 3. Fluorescence microscopy analysis of the effect of arsenic trioxide, cobalt chloride and curcumin on the morphology of MCF-7 cells. Analysis of morphological effects of the cell cycle and apoptosis inducers, arsenic trioxide, cobalt chloride and curcumin on MCF-7 cells. DAPI staining showed an increase in the mitotic cells (white unbroken arrow) and the apoptotic cells (white dotted arrow) after (B \& E) arsenic trioxide, (C) cobalt chloride and (F) curcumin treatments compared with untreated cells ( $3 A$ and $D$ with white arrow heads).

\section{Arsenic trioxide induces caspase-dependent mode of death in MCF-7 cells}

Caspase activation correlates with the onset of apoptosis and caspase inhibition attenuates apoptosis. Therefore, the involvement of caspases in arsenic trioxide-induced cell death in MCF-7 cells was investigated (Figures 6 \& 7 ). As shown in Figure 6, the percentage of MCF-7 cells undergoing caspase-dependent mode of death after treatment with $11 \mu \mathrm{M}$ of arsenic trioxide was found to be $51 \%$ (Figure $6 \mathrm{~B}$ ). When the concentration of arsenic trioxide was increased to $32 \mu \mathrm{M}$, the percentage of cells undergoing caspase-dependent death also increased to $74 \%$ (Figure 6C) compared with the untreated control (Figure 6A). The same trend was observed in the positive control $(100 \mu \mathrm{M}$ of curcumin) that showed 67\% (Figure 6D).

\section{Arsenic trioxide induces apoptosis in MCF-7 cells}

To further confirm that arsenic trioxide treatment induced apoptosis in MCF-7 cells, the MUSE ${ }^{\circledR}$ Annexin V analysis was performed. Upon observation under the microscope, MCF-7 cells demonstrated apoptotic changes after treatment with 11 and $32 \mu \mathrm{M}$ of arsenic trioxide but untreated cells maintained their epithelial morphology and remained attached on the culture flasks. The Muse Annexin $V$ analysis showed that arsenic trioxide remarkably induced apoptosis in MCF-7 cells. As shown in Figures $8 \&$ 9, percentage of cells undergoing apoptosis after treatment with $11 \mu \mathrm{M}$ of arsenic trioxide was $44 \%$ (Figure $8 \mathrm{~B}$ ) and when the concentration of arsenic trioxide was increased to $32 \mu \mathrm{M}$, the apoptosis percentage increased to $60 \%$ (Figure $8 \mathrm{C}$ ) when compared with the untreated control (Figure 8A), the same trend was observed in the positive control (100 $\mu \mathrm{M}$ of curcumin) that induced $61 \%$ apoptosis (Figure 8D) in MCF-7 cells.

\section{Arsenic trioxide regulates the expression of RBBP6 transcripts}

Messenger RNA (mRNA) levels of RBBP6 transcripts in MCF-7 cells treated with arsenic trioxide (11 and $32 \mu \mathrm{M})$, curcumin $(100 \mu \mathrm{M})$ and cobalt chloride $(100 \mu \mathrm{M})$ for $24 \mathrm{~h}$ were analyzed using the conventional-PCR to determine 
(A)

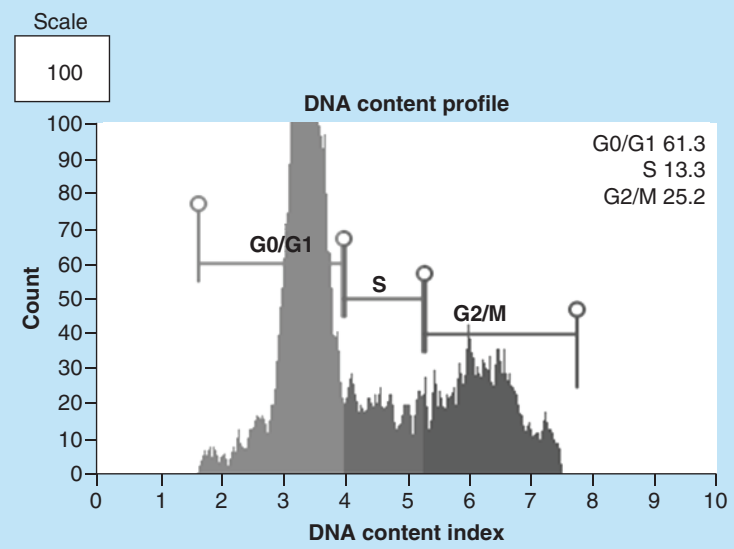

(B)

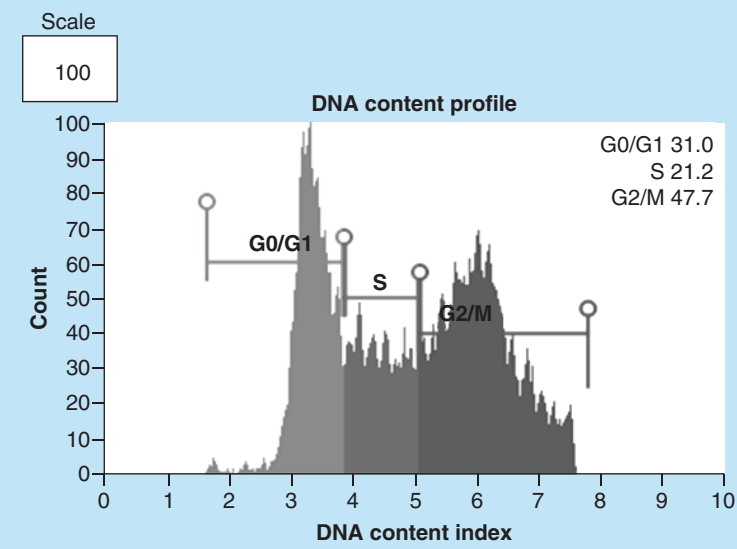

(c)

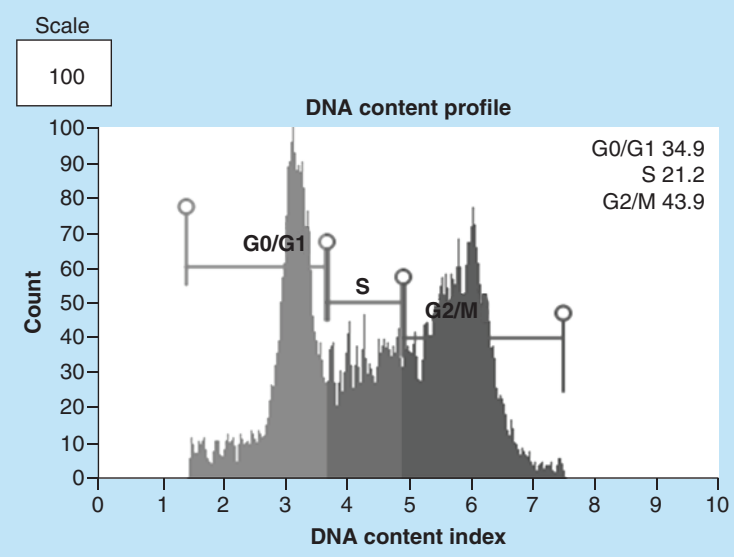

Figure 4. Cell cycle analysis of arsenic trioxide induced G2/M cell cycle arrest in MCF-7 cells. Distribution of MCF-7 cells at distinct cell cycle phases after the treatment with (4B) arsenic trioxide and (4C) cobalt chloride compared with the untreated cells. Treatment with $11 \mu \mathrm{M}$ arsenic trioxide and $100 \mu \mathrm{M}$ of cobalt chloride (positive control) resulted with increased G2/M cell cycle arrest in MCF-7 cells when compared with (4A) the untreated control.

Figure 5. Graphical analysis of arsenic trioxide induced G2/M cell cycle arrest in MCF-7 cells MCF-7 cells. Arsenic trioxide $(11 \mu \mathrm{M})$ and cobalt chloride $(100 \mu \mathrm{M})$ induced $\mathrm{G} 2 / \mathrm{M}$ arrest relative to the untreated MCF-7 cells. Results were obtained from three independent experiments and were presented as \pm SEM and the differences were considered significant when * $p$ was $\leq$ $0.05, * * p \leq 0.01$ and $* * * p \leq 0.0001$.

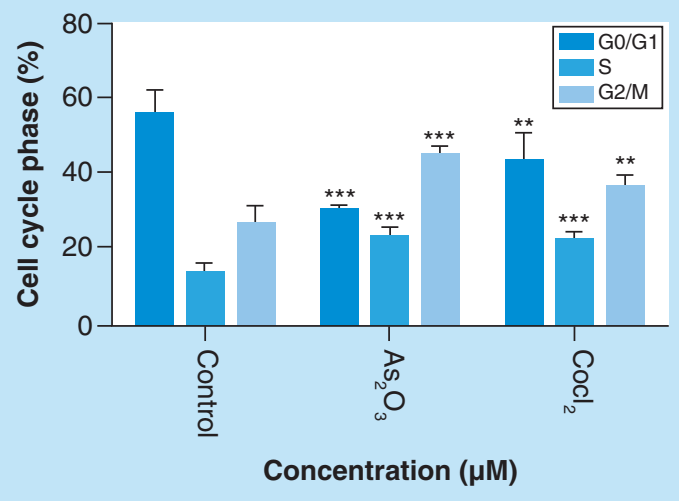


(A)

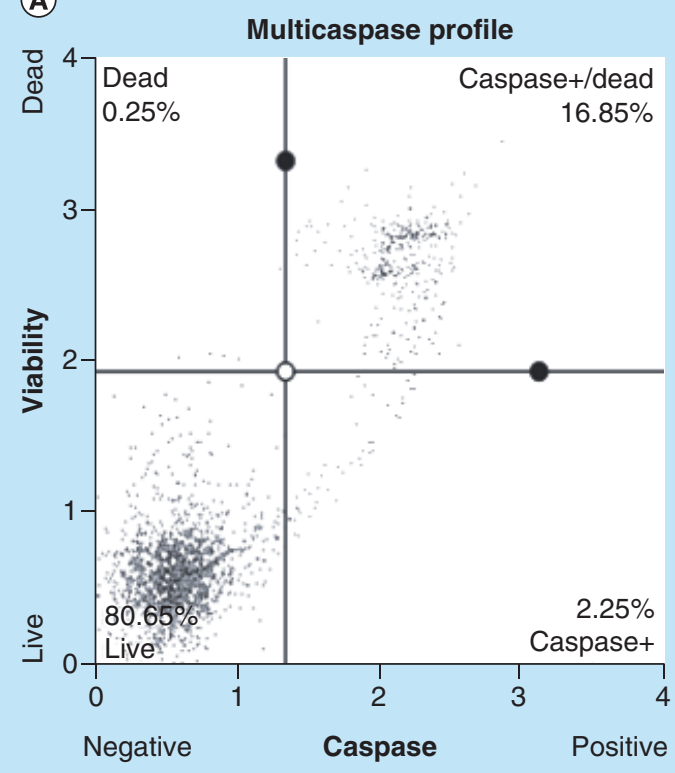

(C)

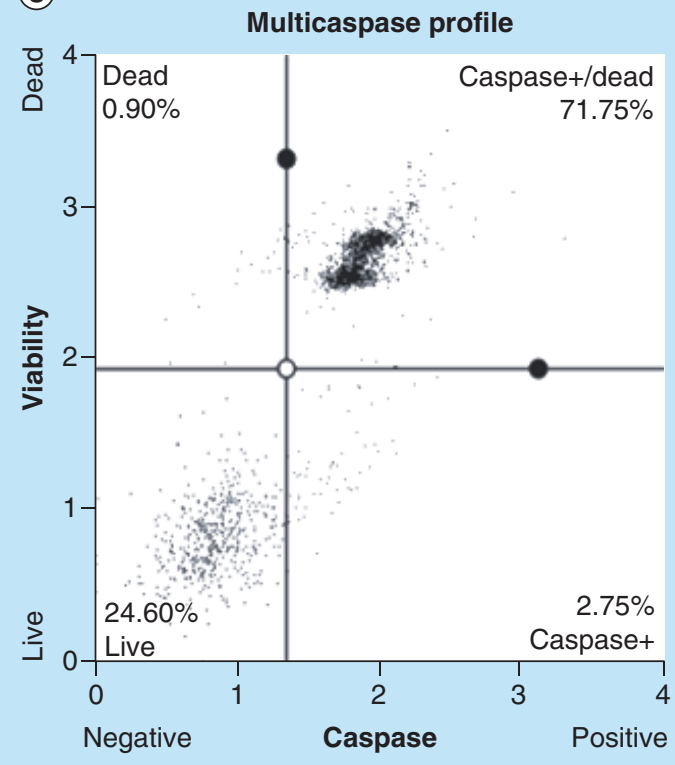

(B)

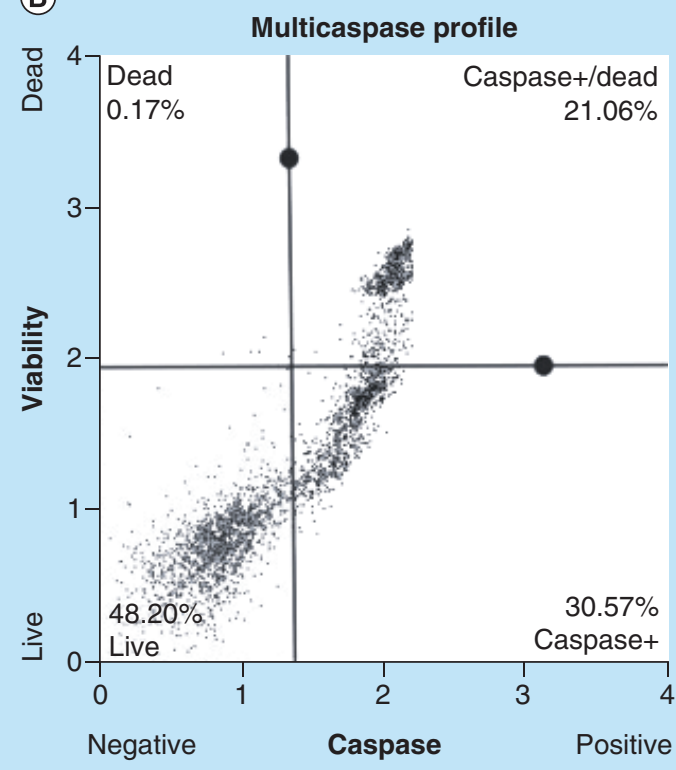

(D)

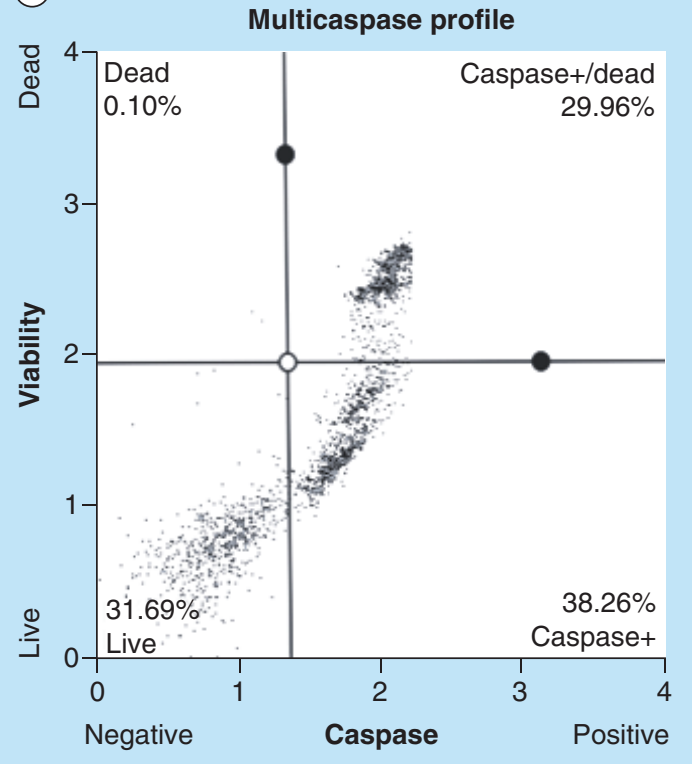

Figure 6. Analysis of arsenic trioxide induced caspase dependent apoptosis in MCF-7 cells. Caspase induction by arsenic trioxide and curcumin in MCF-7 cells. The MUSE ${ }^{\circledR}$ Multi-capsase Analysis confirmed that treatment with 11 and $32 \mu \mathrm{M}$ of (B \& C) arsenic trioxide and $100 \mu \mathrm{M}$ of the positive control, (D) curcumin induced caspase-dependent mode of death in MCF-7 cells when compared with $(A)$ the untreated control.

whether the $R B B P G$ can be implicated in the observed arsenic trioxide-induced cell cycle arrest and apoptosis. The $R B B P 6$ variant 1 was found to be highly upregulated in the untreated MCF-7 cells when compared with the treated MCF-7 cells. Arsenic trioxide-, cobalt chloride-induced cell cycle arrest and arsenic trioxide- and curcumin-induced apoptosis downregulated the expression of $R B B P G$ variant 1 . However, these compounds did not induce detectable levels of variant 2 (lanes 2-5 in Figure 10A) nor RBBP6 variant 4, which remains elusive and undetectable. 


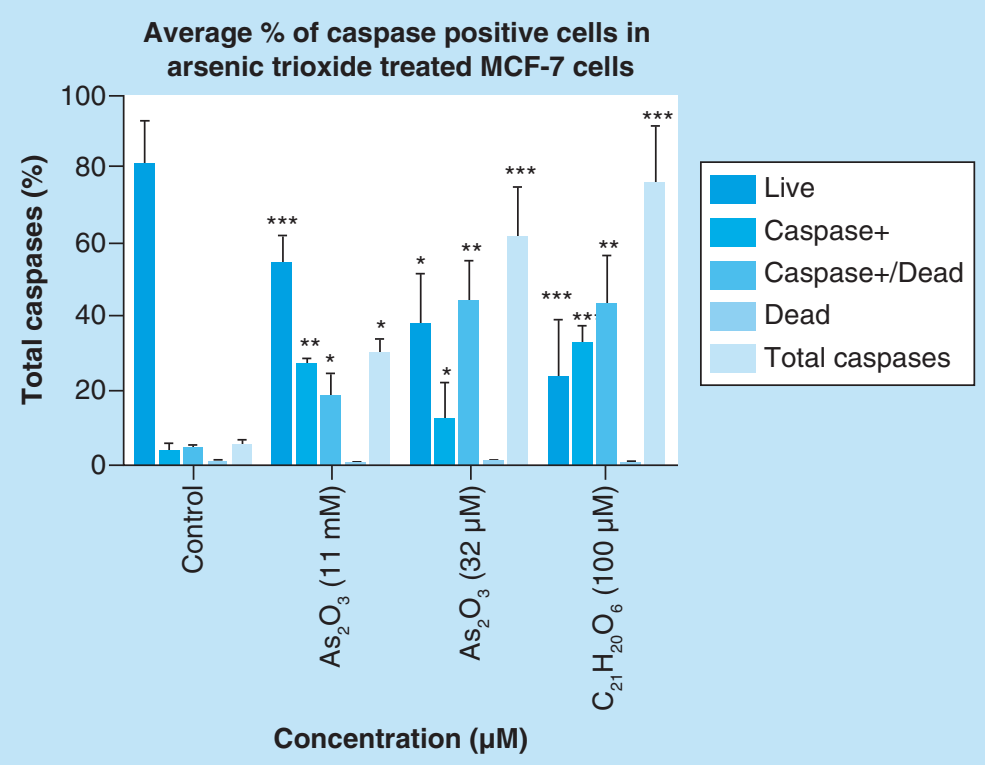

Figure 7. Graphical analysis of arsenic trioxide induced caspase dependent apoptosis in MCF-7 cells. Treatment with arsenic trioxide $(11$ and $32 \mu \mathrm{M})$ and curcumin $(100 \mu \mathrm{M})$ for $24 \mathrm{~h}$ induced caspase-dependent mode of death in MCF-7 cells relative to the untreated control. Results were obtained from three independent experiments and were presented as \pm standard error of the mean and the differences were considered significant when ${ }^{*} p$ was $\leq 0.05,{ }^{* *} p$ $\leq 0.01$ and $* * * p \leq 0.0001$.

$G A P D H$ was used as a control to ascertain that equal amounts of the cDNAs from untreated and treated samples were used. Figure 10C (lanes 1-3) showed that normal cells (Hek 293 cells) express both variants 1 and 2 with the latter downregulated in breast cancer MCF-7 cells. Treatment of breast cancer cells with both arsenic trioxide and curcumin resulted in downregulation of the RBBP6 variant 1 in breast cancer cells as shown in Figure 10A (lanes $2,3,5)$, respectively. On the contrary, for the first time, we show that MCF-7 cells either do not express RBBP6 variant 2 or these cells express this variant at undetectable levels. Our results quantified from three independent experiments using Quantity One ${ }^{\circledR} 1 \mathrm{D}$ analysis software (Figure 11 ) showed that variant 1 is highly expressed in MCF-7 cells and is downregulated by apoptosis inducers, arsenic trioxide and curcumin.

The mRNA levels of RBBP 6 variant 3 were also determined using conventional-PCR. Figure 12 shows that the $R B B P 6$ variant 3 is expressed by normal embryonic kidney cells compared with the breast cancer cells. The blank controls (Figure 12, lanes BL) showed no product as expected. The untreated Hek 293 cells (Figure 12A, lane 3) showed expression of the RBBPG variant 3 while RBBPG variant 3 was undetectable in MCF-7 cells (Figure 12A, lane 1) and in cervical Caski cells (Figure 12A, lane 2). These results were quantified from three independent experiments using Quantity One ${ }^{\circledR} 1 \mathrm{D}$ analysis software (Figure 13). Our results showed that both variants 2 and 3 were undetectable in cancer cells, especially breast cancer MCF-7 cells and cervical cancer Caski cells. This suggests that both variants 2 and 3 may be crucial in maintaining cell homeostasis, which is lost during carcinogenesis while the expression of variant 1 may favor the carcinogenesis process.

\section{Arsenic trioxide regulates the expression of Bax protein in MCF-7 cells}

In this section, the effect of arsenic trioxide on Bax expression was investigated. Bax protein is lowly expressed in MCF-7 breast cancer cells (Figure 14C \& D) because it is involved in the induction of apoptosis, which is a process that is inhibited in breast cancer. The treatment of MCF-7 breast cancer cells with arsenic trioxide showed increased expression of Bax protein (Figure 14E-H). The same trend was observed in curcumin (Figure 14K \& L) treated cells while cobalt-induced cell cycle arrest did not have increased significant effect in the expression of Bax (Figure 14I \& J). These results (Figure $14 \& 15$ ) show that arsenic trioxide is not only inducing apoptosis, cell cycle arrest and regulating the expression of RBBP6 variants but it also upregulates the expression of Bax protein 
(A)

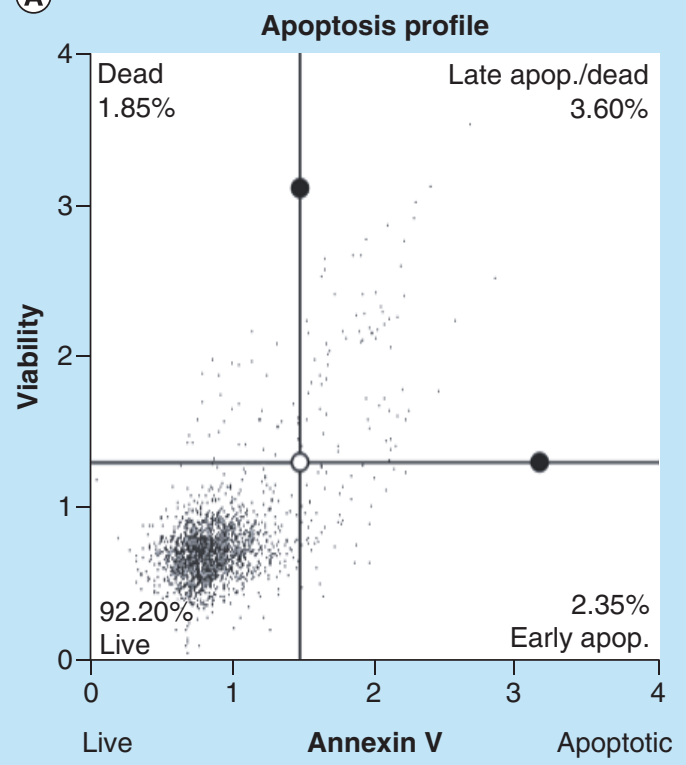

(C)

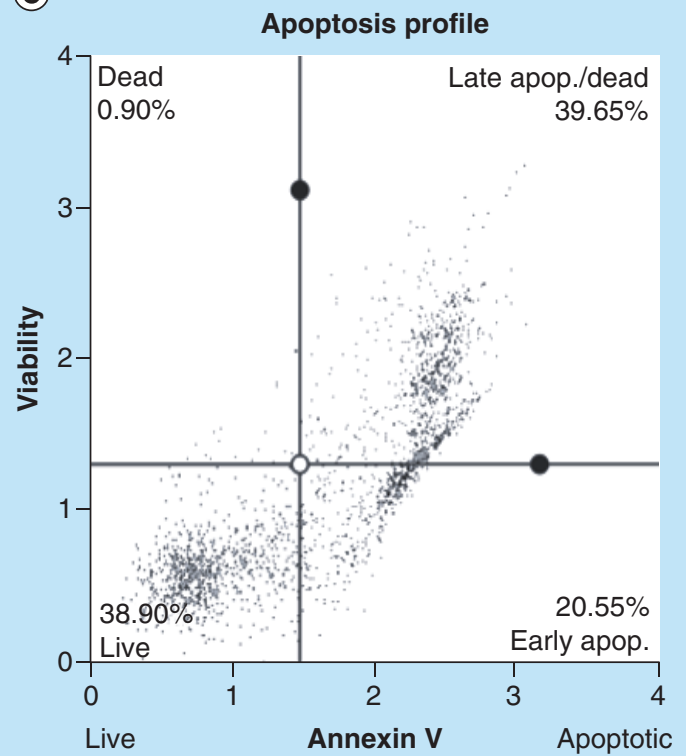

(B)

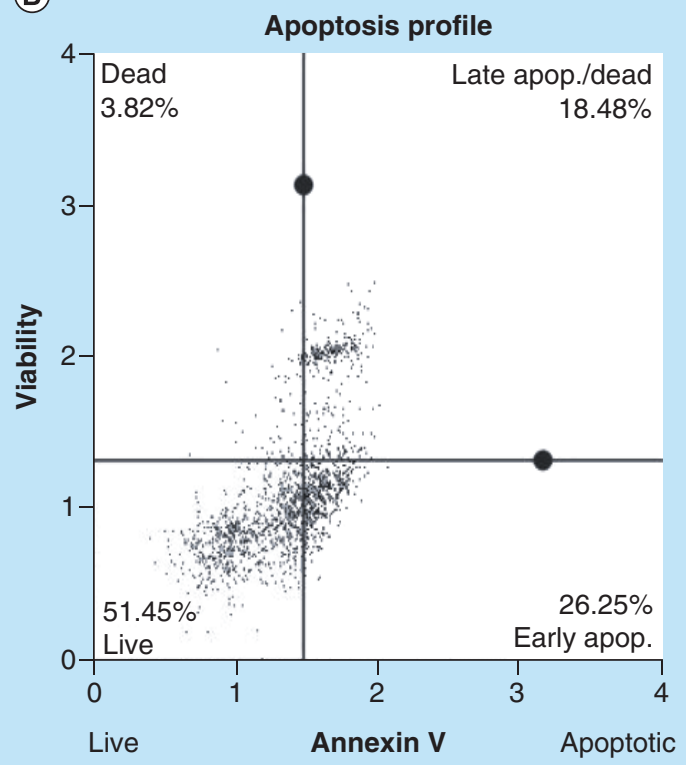

(D)

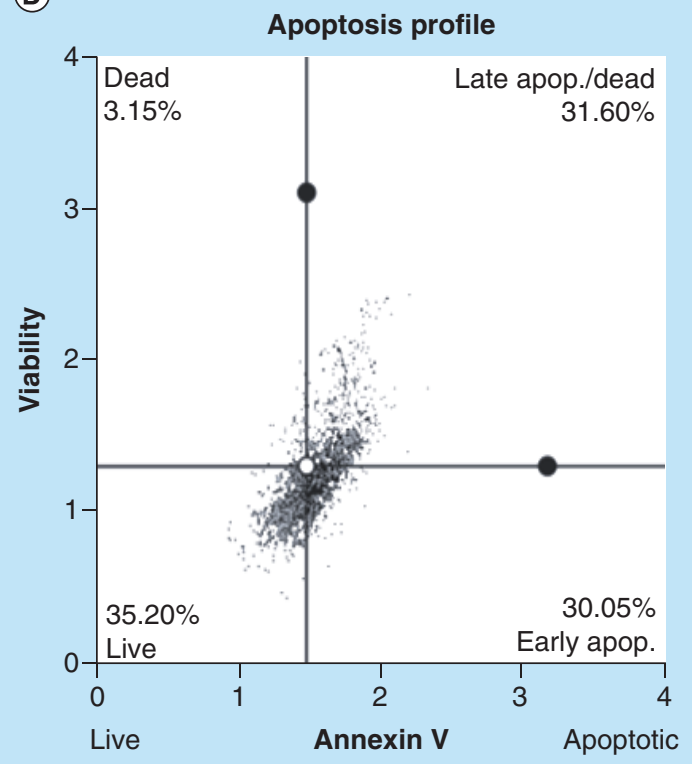

Figure 8. Analysis of arsenic trioxide induced apoptosis in MCF-7 cells. Apoptosis induction by arsenic trioxide and curcumin in MCF-7 cells. The MUSE ${ }^{\circledR}$ Apoptosis Analysis confirmed that treatment with 11 and $32 \mu \mathrm{M}$ of (B \& C) arsenic trioxide and $100 \mu \mathrm{M}$ of the positive control, (D) curcumin induced apoptosis in MCF-7 cells when compared with (A) the untreated control.

in MCF-7 breast cancer cells, which suggest that RBBP6 variant 1 downregulation may be involved in the intrinsic apoptotic pathway.

\section{Discussion}

This study showed that $R B B P G$ variant 1 may be involved in breast cancer development and its expression in breast cancer cells may promote cell survival. It is not surprising that upon apoptosis induction, this variant is downregulated. On the other hand, the smaller RBBPG variant 3 might be involved in the regulation of cell cycle 


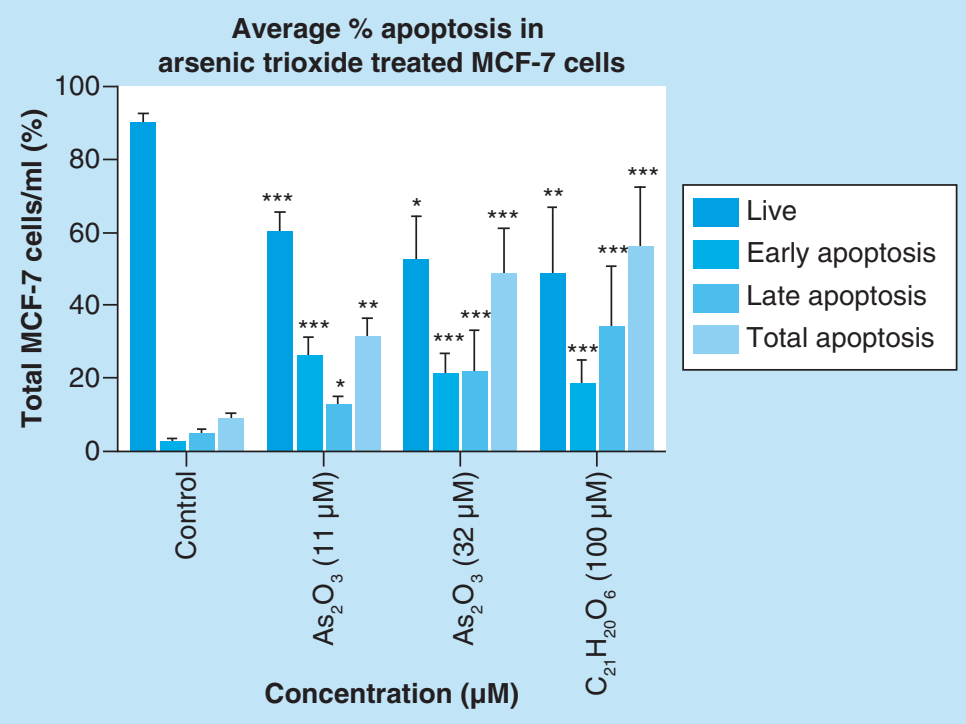

Figure 9. Graphical analysis of arsenic trioxide induced apoptosis in MCF-7 cells. Treatment with arsenic trioxide (11 and $32 \mu \mathrm{M})$ and curcumin $(100 \mu \mathrm{M})$ for $24 \mathrm{~h}$ induced apoptosis mode of death in MCF-7 cells relative to the untreated control. Results were obtained from three independent experiments and were presented as \pm standard error of the mean and the differences were considered significant when * $p$ was $\leq 0.05, * * p \leq 0.01$ and $* * * p \leq 0.0001$.

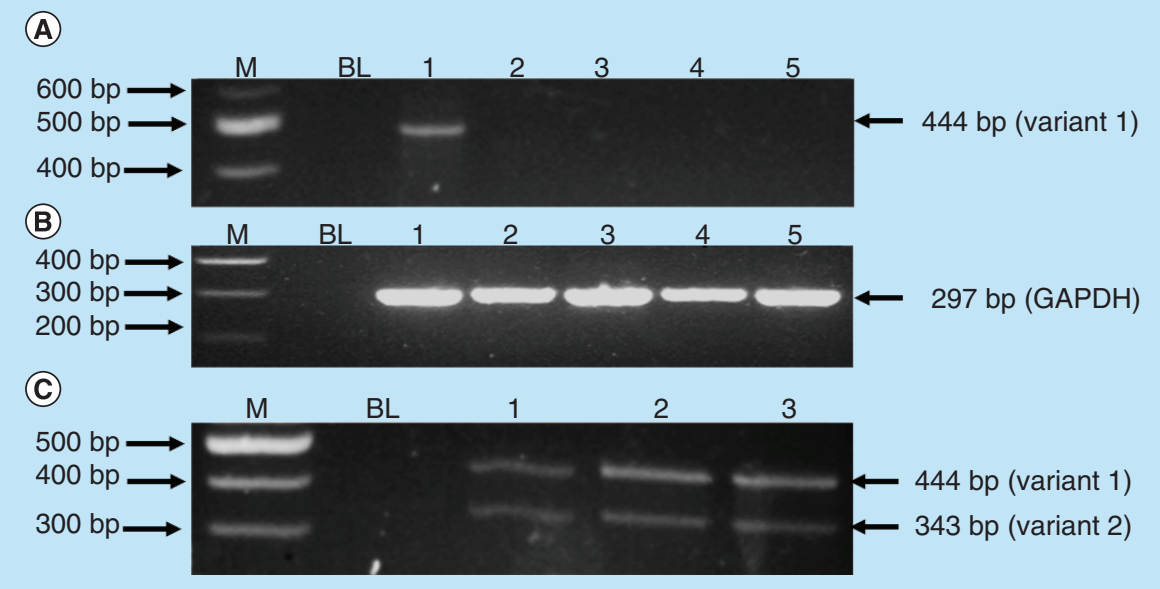

Figure 10. Expression analysis of RBBP6 variant 1 and 2 in arsenic trioxide treated MCF-7 cells and untreated Hek 293 cells. Amplification of RBBP6 variants in MCF-7 cells and Hek-293 cells. The primers were designed both upstream and downstream the exon 16 region to amplify both variants 1 and 2 . The results (A) show untreated MCF-7 cells (lane 1) expressing variant 1, treatment with $11 \mu \mathrm{M}$ of $\mathrm{As}_{2} \mathrm{O}_{3}$ (lane 2), treatment with $32 \mu \mathrm{M}$ of $\mathrm{As}_{2} \mathrm{O}_{3}$ (lane 3), treatment with $100 \mu \mathrm{M}$ cobalt chloride (lane 4) and at last treatment with $100 \mu \mathrm{M}$ curcumin (lane 5), all showing repressed expression of variant 1. (B) (Lanes 1-5) represent GAPDH that was used as a loading control. Lanes $M$ stand for the molecular weight marker while lanes BL were blank controls. (C) (Lanes 1-3) show the expression of both variants 1 and 2 by the untreated Hek 293 cells.

arrest, especially G2/M cell cycle arrest as previously shown in kidney embryonic cells [4], which was undetectable in breast cancer cells. Downregulation of cell cycle regulatory biomolecules favors the carcinogenesis process, hence downregulation of $R B B P G$ variant 3 in breast cancer is not surprising. It should be stressed that apoptosis is a well-defined and probably the most frequent form of programmed cell death, but nonapoptotic types of cell death might also be of biological significance [12]. 


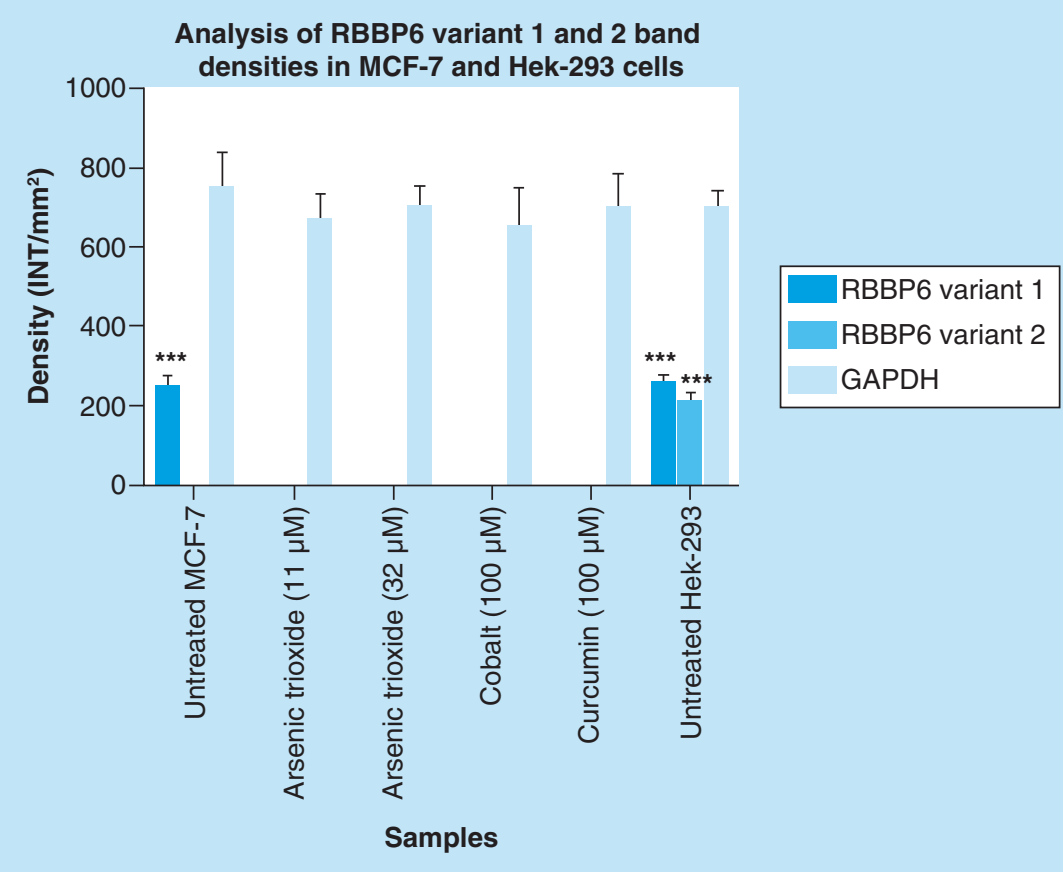

Figure 11. Graphical analysis of RBBP6 variant 1 and variant 2 band densities in MCF-7 and untreated Hek-293 cells. Untreated MCF-7 cells significantly (*** $\mathrm{x} \leq 0.001$ ) show increased band intensity of the RBBP6 variant 1 which diminished after treatment with arsenic trioxide, cobalt chloride and curcumin. Untreated MCF-7 cells did not show any expression of RBBP6 variant 2, with only untreated Hek-293 cells showing detectable levels of both RBBP6 variants 1 and 2 . Results were obtained from three independent experiments and were presented as \pm standard error of the mean and the differences were considered significant when $* * * p<0.001$ ). The density was measured using Quanty-One software.

(A)

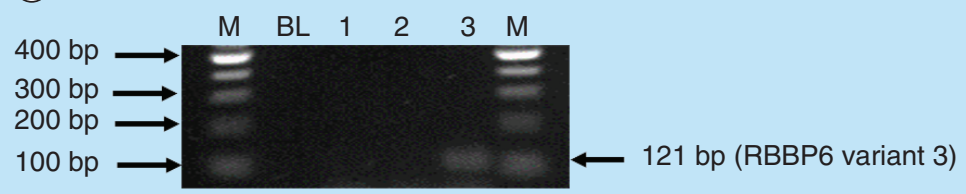

(B) $\begin{array}{llllll}M & B L & 1 & 2 & 3 & M\end{array}$

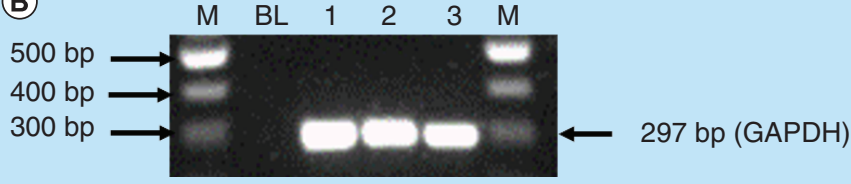

Figure 12. (A \& B) Expression analysis of RBBP6 variant 3 in untreated MCF-7, Caski and Hek-293 cells. Amplification of RBBP6 variant 3 in MCF-7 cells, Caski cells and Hek 293 cells. The result (A) shows untreated MCF-7 cells (lane 1) and untreated Caski cells (lane 2) both with an undetectable expression of RBBP6 variant 3, only untreated Hek 293 cells (lane 3) show the expression of RBBP6 variant 3. (B) (Lanes 1-3) represent GAPDH that was used as a loading control. Lanes M stand for the molecular weight marker while lanes BL were blank controls.

Breast cancer cells are resistant to apoptosis, consequently, growing uncontrollably. In this study, we have shown that breast cancer cells may have lost the expression of $R B B P C$ variants 2 and 3 in favor of the carcinogenesis process. $R B B P 6$ variant 4 has not been demonstrated but it is likely that it is one of the anticancer variants, which may be critical for maintaining cell homeostasis. RBBPG has a wide range of functions and these include a role in cell cycle regulation, apoptosis, protein stability and mRNA processing $[8,13,14]$. RBBP6 has been shown to induce 
Figure 13. Graphical analysis of RBBP6 variant 3 band densities in untreated MCF-7, Caski and Hek-293 cells. Both untreated MCF-7 and Caski cells had undetectable expression of RBBP6 variant 3, only untreated Hek-293 cells show detectable levels of RBBP6 variant 3 . Results were obtained from three independent experiments and were presented as \pm standard error of the mean and the differences were considered significant when ** $p<$ 0.001 . The density was measured using Quanty-One software.

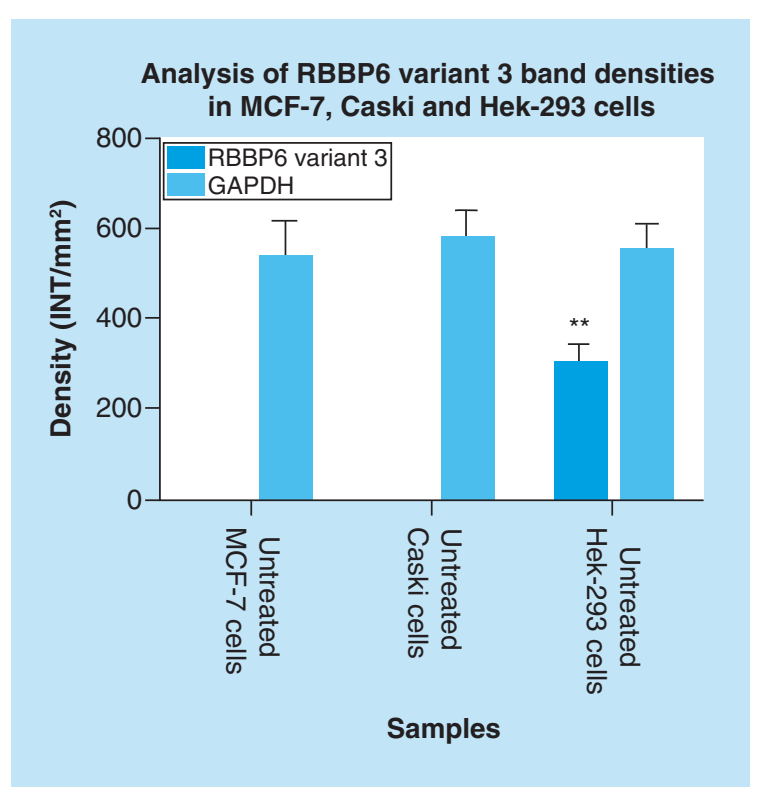

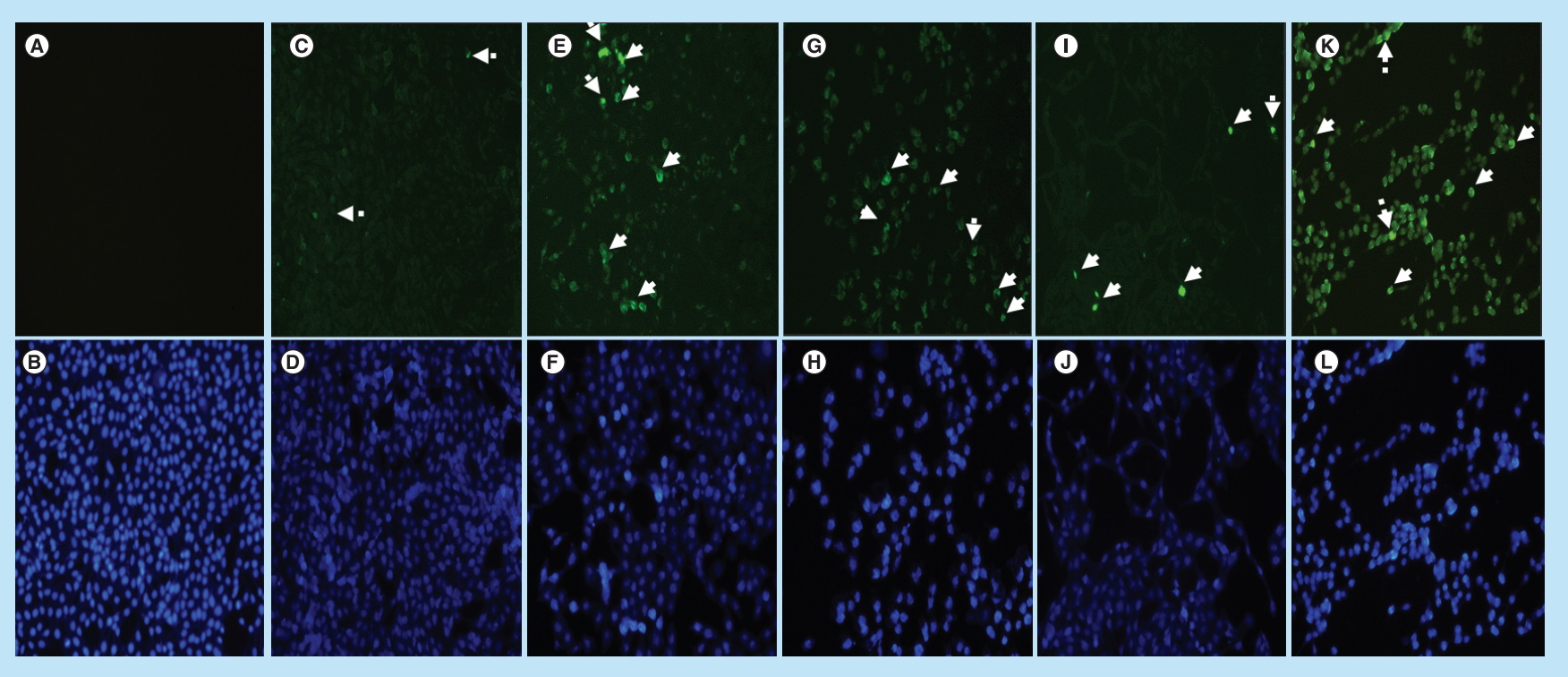

Figure 14. Analysis of Bax localization and expresssion in MCF-7 cells. Localization and expression of Bax in MCF-7 cells counterstained with DAPI. The results show (A \& B) a negative control, no labeling is seen. (C-L) Micrographs show positive Bax staining in the nucleus and cytoplasm. MCF-7 cells show less expression of Bax in (C \& D) untreated cells because apoptosis is inhibited in these cells, but the treatment with $(\mathrm{E}-\mathrm{H})$ arsenic trioxide upregulated the expression of this protein. The same trend was observed even in the positive controls, (I \& J) cobalt chloride and (K \& L) curcumin which also regulated the expression of Bax protein. White arrows point to mitotic cells with increased Bax staining levels. Magnification $20 \times$.

cell cycle progression by ubiquitinating p53 through Murine Double Minute 2 (MDM2), therefore, promoting carcinogenesis [3]. RBBPG variant 1 has ubiquitin ligase activity and this activity leads to enhanced degradation of $\mathrm{p} 53$, the cell guardian, which is crucial for antitumor formation. Furthermore, $R B B P 6$ variant 3 is involved in G2/M arrest, but its absence triggers cell cycle progression and high proliferation rates in normal kidney cells [4]. Consequently, it would be advantageous for cancer cells not to express this variant to support their rapid growth. Some lines of evidence showed that the enhanced expression of different $R B B P G$ variants correlate with poor clinical prognosis in colon, prostate and esophageal cancer [15-17]. Breast cancer treatment remains a challenge and therefore, 


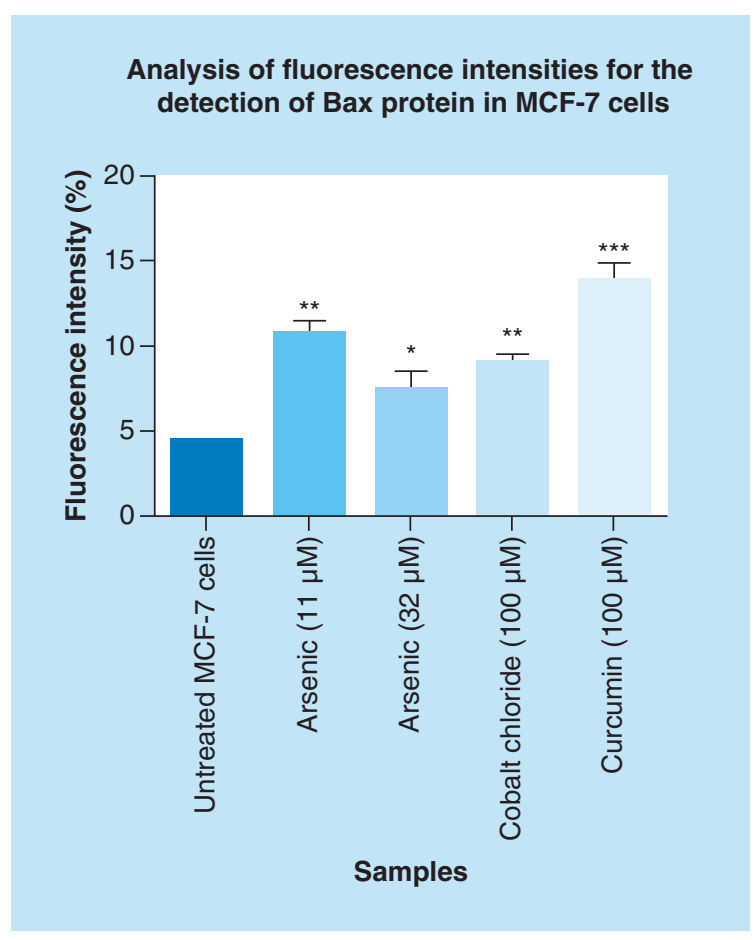

Figure 15. Graphical analysis of fluorescence intensities for the detection of Bax protein in MCF-7 cells. Arsenic trioxide upregulated the expression of Bax protein when compared with the untreated control. The same trend was observed even with the positive controls (cobalt chloride and curcumin). Results were obtained from three independent experiments and were presented as \pm standard error of the mean and the differences were considered significant when * $p$ was $\leq 0.05, * * p \leq$ 0.01 and $* * * p \leq 0.0001$. The fluorescence intensity was measured using the Image J software (https://imagej.nih.gov/ij/docs/index.html).

there is a need for more specific and effective therapeutic tools. $R B B P 6$ is a promising therapeutic target and there are a lot of promising drug development targets, such as arsenic trioxide $\left(\mathrm{As}_{2} \mathrm{O}_{3}\right)$.

$\mathrm{As}_{2} \mathrm{O}_{3}$ is a potent US FDA approved drug confirmed to treat acute promyelocytic leukemia in patients that relapsed after chemotherapy. Arsenic trioxide exhibits therapeutic effects in a variety of human cancers such as human hepatocellular carcinoma, gastric cancer and cervical cancer [18-20]. Arsenic trioxide hinders cancer development and progression through targeting cellular pathways, leading to inhibition of cell proliferation and invasion, and promoting apoptosis. Little is known about the expression and regulation of the human RBBP6 splice variants by arsenic trioxide during cell cycle progression and breast cancer development. Therefore, in this study, arsenic trioxide was chosen due to its antitumor effect in a variety of human cancers [18-20]. The effect of arsenic trioxide on MCF-7 cells was compared with the positive controls (curcumin and cobalt chloride) because these cytotoxic agents have also been shown to induce cell cycle arrest and apoptosis in cancer cells [10,11]. As previously shown, both the positive controls (curcumin and cobalt chloride) consistently induced apoptosis and cell cycle arrest, respectively in MCF-7 breast cancer cells.

This study has shown that arsenic trioxide and curcumin-induced cell cycle arrest and apoptosis in breast cancer MCF-7 cells, respectively (Figure 1-9). These findings support the results of previous studies showing similar effects on gynecological cancers and other solid tumors [9-11,21]. These findings suggest that $\mathrm{As}_{2} \mathrm{O}_{3}$, cobalt chloride and curcumin should additionally be investigated as potential novel chemotherapeutic agents for the adjuvant treatment of malignant human tumors. It was evident that the untreated control cells retained normal morphology and attached firmly to the culture plates with random orientation (Figure 2), while cells treated with arsenic trioxide, cobalt chloride and curcumin showed remarkable cellular effect, which included decrease in cell numbers, rounding effects, decrease in cell size, detachment from the substratum. Furthermore, DAPI staining (Figure 3B \& E) confirmed that arsenic trioxide induced cell cycle arrest and apoptosis that was shown by loss of cell microvilli, nuclear condensation and formation of apoptotic bodies.

Quantitative analysis of apoptotic cells and cell cycle arrest (Figures 4-9) using the MUSE Cell Analyzer demonstrated that $\mathrm{As}_{2} \mathrm{O}_{3}$ induced evident caspase-dependent apoptosis but not necrosis in MCF-7 cells. It was also observed that arsenic trioxide induced G2/M arrest in MCF-7 cells (Figure 4B). The G2/M arrest did not only inhibit the proliferation of cells but also triggered several apoptosis features that were evident after DAPI staining. These results suggest that $\mathrm{As}_{2} \mathrm{O}_{3}$-induced growth inhibition mainly depended on the induction of caspasedependent apoptosis and cell cycle arrest in MCF-7 cells. These results further showed that caspases are involved in arsenic trioxide induced apoptosis (Figures $6 \& 7$ ). They support a study which was done in MCF-7 breast 
cancer cells to show that $\mathrm{As}_{2} \mathrm{O}_{3}$ exposure significantly increases the level of caspase-3 [22]. The upregulation of caspase 3 by arsenic trioxide was also shown in HT-29 colon cancer cells, suggesting that arsenic trioxide induces caspase-3-dependent pathway [23]. Even though caspase-3 has been previously reported to be inactivated in MCF-7 cells [24], this study has shown that caspase-dependent apoptosis is induced by arsenic trioxide and curcumin and $R B B P 6$ variant 1 may be critical in the process. Other effector caspases may be involved in the induced apoptosis in MCF-7 cells. There are contradictory reports on the expression of caspase- 3 in MCF-7 but it is possible that the mutated form responds to different apoptosis inducers [25].

We further showed that arsenic trioxide and curcumin regulate the expression of $R B B P G$ variants, especially the two big transcripts; variants 1 and 2 (Figures $10 \& 11$ ). Figure $10 \mathrm{~A}$ (lane 1) demonstrated that breast cancer cells express $R B B P 6$ variant 1 and lack the expression of variant 2 . Treatment of these cells with arsenic trioxide, cobalt chloride and curcumin diminished the expression of $R B B P 6$ variant 1 . This suggested that this variant may promote breast cancer development while diminished expression of variant 2 may also support carcinogenesis. We previously suggested that $R B B P 6$ variants and isoforms may have opposing cellular functions [4]. In this study, we showed that RBBPG variant 3 is expressed in noncancerous cells, Hek $293 \mathrm{~s}$ but undetectable in breast MCF-7 cancer cells (Figures 12 \& 13). We also showed that noncancer cells, at least, in Hek 293, express both variants 1 and 2. Arsenic trioxide did not only regulate the expression of $R B B P 6$ transcripts but also regulated the expression of apoptosis-related protein, Bax (Figure 14). These results showed that $\mathrm{As}_{2} \mathrm{O}_{3}$ is effective against MCF-7 cells and also regulates the expression of $R B B P G$ variants, especially variant 1 , which makes both $R B B P 6$ variant 1 and arsenic trioxide an important therapeutic target.

\section{Conclusion}

This study showed that there are $R B B P 6$ variants that are procarcinogenic and those that are anticarcinogenic. Different $R B B P G$ variants could be targeted for cancer therapeutic development. In conjunction with $R B B P 6$ expression, arsenic trioxide, cobalt chloride and curcumin should be further explored as cancer drugs.

\section{Future perspective}

Little is known about the expression and regulation of the human RBBP6-spliced variants by arsenic trioxide, cobalt chloride and curcumin during cell cycle progression and breast cancer development. Taken together our findings indicate that arsenic trioxide, cobalt chloride and curcumin have substantial bioactivity against MCF-7 cells and regulate the expression of $R B B P 6$ variants. This will allow scientists to target RBBP6 and these cytotoxic agents for future drug development. Further investigations using animal models and other breast cancer types are needed to provide new insights into the potential application of these cytotoxic agents in the treatment of breast cancer and regulation of RBBP6.

\section{Summary points}

- Arsenic trioxide, curcumin and cobalt chloride decreased the viability of the MCF-7 breast cancer cells in a dose-dependent manner.

- Arsenic trioxide and curcumin-induced, caspase-dependent apoptosis in MCF-7 breast cancer cells.

- Arsenic trioxide and cobalt chloride induced G2/M cell cycle arrest of the MCF-7 cells.

- RBBP6 variants have opposing functions.

- RBBP6 variant 1 may support the carcinogenesis process in breast cancer MCF-7 cells.

- RBBP6 variant 3 is against the carcinogenesis process and it is downregulated in MCF-7 cells.

- Arsenic trioxide upregulated the expression of Bax protein in MCF-7 breast cancer cells.

- Therefore, our study suggests that there are RBBP6 variants that are procarcinogenic and there are those that are anticarcinogenic. It also suggests that arsenic trioxide regulates both RBBP6 transcripts and Bax protein.

\footnotetext{
Author contributions

L Makgoo and K Laka carried out the experiments and analyzed the data. Z Mbita supervised the work and the analysis. All the authors wrote the manuscript.
}

Acknowledgments

The authors wish to thank M Meyer, University of the Western Cape, for donation of the cells. 
Financial \& competing interests disclosure

This work was financially supported by the National Research Foundation (NRF) of South Africa (UID: 94092) and Department of Biochemistry, Microbiology and Biotechnology Research Funds. The authors have no other relevant affiliations or financial involvement with any organization or entity with a financial interest in or financial conflict with the subject matter or materials discussed in the manuscript apart from those disclosed.

No writing assistance was utilized in the production of this manuscript.

Open access

This work is licensed under the Creative Commons Attribution 4.0 License. To view a copy of this license, visit http://creativecomm ons.org/licenses/by/4.0/

\section{References}

Papers of special note have been highlighted as: $\bullet$ of interest; $\bullet \bullet$ of considerable interest.

1. Siegel RL, Miller KD, Jemal A. Cancer statistics 2015. CA Cancer J. Clin. 65(1), 5-29 (2015).

2. Di Leo A, Curigliano G, Diéras V et al. New approaches for improving outcomes in breast cancer in Europe. Breast 24(4), 321-330 (2015).

3. Li L, Deng B, Xing G et al. PACT is a negative regulator of p 53 and essential for cell growth and embryonic development. Proc. Natl Acad. Sci. USA 104(19), 7951-7956 (2007).

-. Showed that RBBP6 induces or inhibits apoptosis via interaction with $\mathrm{pRB}$ and $\mathrm{p} 53$.

4. Mbita Z, Meyer M, Skepu A, Hosie M, Rees J, Dlamini Z. De-regulation of the RBBP6 isoform 3/DWNN in human cancers. Mol. Cell Biochem. 362(1-2), 249-262 (2012).

- Implicated RBBP6 in cell cycle regulation.

5. Motadi LR, Bhoola KD, Dlamini Z. Expression and function of retinoblastoma binding protein 6 (RBBP6) in human lung cancer. Immunobiology 216(10), 1065-1073 (2012).

- Showed that RBBP6 expression is upregulated in lung cancer.

6. Ntwasa M, Nweke E, Cajee UF. The retinoblastoma binding protein 6 family is essential for embryonic development and carcinogenesis. J. Cancer Res. Forecast 1(1), 2002 (2018).

7. Ntwasa M. Retinoblastoma binding protein 6, another p53 monitor. Trends Cancer 2(11), 635-637 (2016).

-• Reviewed the role of RBBP6 in carcinogenesis.

8. Gao S, Scott RE. P2P-R protein overexpression restricts mitotic progression at prometaphase and promotes mitotic apoptosis. J. Cell. Physiol. 193(2), 199-207 (2002).

-• Showed that P2P-R (RBBP6 rat homolog) is pro-apoptotic.

9. Baj G, Arnulfo A, Deaglio $S$ et al. Arsenic trioxide and breast cancer: analysis of the apoptotic, differentiative and immunomodulatory effects. Breast Cancer Res. Treat. 73(1), 61-73 (2002).

10. Choudhuri T, Pal S, Agwarwal ML, Das T, Sa G. Curcumin induces apoptosis in human breast cancer cells through p53-dependent Bax induction. FEBS Lett. 512(1-3), 334-340 (2012).

11. Bae $\mathrm{S}$, Jeong $\mathrm{HJ}$, Cha HJ et al. The hypoxia-mimetic agent cobalt chloride induces cell cycle arrest and alters gene expression in U266 multiple myeloma cells. Int. J. Mol. Med. 30(5), 1180-1186 (2012).

12. Foghsgaard L, Wissing D, Mauch D et al. Cathepsin B acts as a dominant execution protease in tumour cell apoptosis induced by tumour necrosis factor. J. Cell Biol. 153(5), 999-1010 (2001).

13. Pugh DJ, Eiso AB, Faro A, Lutya PT, Hoffmann E, Rees DJG. DWNN, a novel ubiquitin-like domain, implicates RBBP6 in mRNA processing and ubiquitin-like pathways. BMC Struct. Biol. 6(1), 1 (2006).

- Implicated RBBP6 in pre-mRNA processing.

14. Chibi M, Meyer M, Skepu A, Rees DJG, Moolman-Smook JC, Pugh DJ. RBBP6 interacts with multifunctional protein YB-1 through its RING finger domain, leading to ubiquitination and proteosomal degradation of YB-1. J. Mol. Biol. 384(4), 908-916 (2008).

15. Chen J, Tang H, Wu Z, Zhou C, Jiang T, Xue Y et al. Overexpression of RBBP6, alone or combined with mutant TP53, is predictive of poor prognosis in colon cancer. PLoS ONE 8(6), e66524 (2013).

- Showed that the expression of RBBP6 is upregulated in colon cancer.

16. Singh J, Mnickam P, Shmoish M et al. Annotation of androgen dependence to human prostate cancer-associated genes by microarray analysis of mouse prostate. Cancer Lett. 237(2), 298-304 (2006).

- Showed that the expression of RBBP6 is upregulated in prostate cancer.

17. Yoshitake $\mathrm{Y}, \mathrm{Nakatsura} \mathrm{T}$, Monji $\mathrm{M}$ et al. Proliferation potential-related protein, an ideal oesophageal cancer antigen for immunotherapy, identified using complementary DNA microarray analysis. Clin. Cancer Res. 10, 6437-6448 (2004). 
18. Jiang L, Wang L, Chen $\mathrm{L}$ et al. $\mathrm{As}_{2} \mathrm{O}_{3}$ induces apoptosis in human hepatocellular carcinoma HepG2 cells through a ROS-mediated mitochondrial pathway and activation of caspases. Int. J. Clin. Exp. Med. 8(2), 2190 (2015).

19. Gao YH, Zhang HP, Yang SM et al. Inactivation of Akt by arsenic trioxide induces cell death via mitochondrial-mediated apoptotic signalling in SGC-7901 human gastric cancer cells. Oncol. Rep. 31(4), 1645-1652 (2014).

20. Chun YJ, Park IC, Park M et al. Enhancement of radiation response in human cervical cancer cells in vitro and in vivo by arsenic trioxide $\left(\mathrm{As}_{2} \mathrm{O}_{3}\right)$. FEBS Lett. 519(1-3), 195-200 (2002).

21. Kanzawa T, Kondo Y, Ito H, Kondo S, Germano I. Induction of autophagic cell death in malignant glioma cells by arsenic trioxide. Cancer Res. 63(9), 2103-2108 (2003).

22. Wang $Y$, Zhang $Y$, Yang $L$ et al. Arsenic trioxide induces the apoptosis of human breast cancer MCF-7 cells through activation of caspase-3 and inhibition of HERG channels. Exp. Ther. Med. 2(3), 481-486 (2011).

23. Stevens JJ, Graham B, Dugo E, Berhaneselassie-Sumner B, Ndebele K, Tchounwou PB. Arsenic trioxide induces apoptosis via specific signaling pathways in HT-29 colon cancer cells. J. Cancer Sci. Ther. 9(1), 298 (2017).

24. Jänicke RU. MCF-7 breast carcinoma cells do not express caspase-3. Breast Cancer Res. Treat. 117(1), 219-221 (2009).

25. Paramita D, Wisnubroto JDP. Effect of methylglyoxal on reactive oxygen species, KI-67, and caspase-3 expression in MCF-7 cells. Exp. Mol. Pathol. 105(1), 76-80 (2018). 